\title{
PENGARUH GOOD GOVERNANCE DAN WHISTLEBLOWING SYSTEM TERHADAP KEPATUHAN WAJIB PAJAK DENGAN RISIKO SANKSI PAJAK SEBAGAI MODERASI (STUDI EMPIRIS PADA WAJIB PAJAK DI KABUPATEN SLEMAN)
}

\author{
Syska Lady Sulistyowati ${ }^{1}$, Reza Widhar Pahlevi ${ }^{2}$ \\ ${ }^{1}$ Universitas Widya Dharma \\ syskaladys@gmail.com \\ ${ }^{2}$ Universitas Islam Indonesia \\ rezawidharp@gmail.com
}

\begin{abstract}
Tax compliance still needs to be improved by encouraging the implementation of transparent taxation, namely the transparency of tax management in all areas, both administrative and management of the use of funds derived from tax revenue. The real effort that must be done to implement the transparency is through the bureaucracy reform movement in the service system and tax administration that is through the implementation and implementation of Good Governance.

Good governance is a well-executed organizational governance, by carrying out the principles of openness, justice and accountability in order to achieve the goals of the organization. The problems that will be studied by the researcher is a social and dynamic problem. Therefore, the researcher chooses to use quantitative research method to determine how to find, collect, process and analyze the data of the research result, so that this research is expected to give input for the need of strengthening of harmony between Good Corporate Governance and Whistleblowing System and the need to create system or policies and operational procedures of taxation sanction risk required for tax compliance implementation. The results showed that there is influence between the implementation of Good Corporate Governance to tax compliance, there is influence between Whistleblowing System on tax compliance, there is no influence between the implementation of Good Corporate Governance to tax compliance if moderated by the Taxation Sanction variable and there is influence between the application of Whistleblowing System against tax compliance if it is moderated by the Taxation Sanction variable.
\end{abstract}

Keywords: Good Corporate Governance, Whistleblowing System, Tax Compliance, and Taxation Sanctions.

() 2018 JBTI. All rights reserved

Article history : received 26 Des 2017; revised 5 Jan 2018 ; accepted 15 Jan 2018

\section{PENDAHULUAN}

Kepatuhan pajak merupakan persoalan yang sejak dulu ada di perpajakan. Di dalam negeri rasio kepatuhan wajib pajak dalam melaksanakan pemenuhan kewajiban perpajakannya dari tahun ke tahun masih menunjukkan persentase yang tidak mengalami peningkatan secara berarti. Hal ini didasarkan pada perbandingan jumlah wajib pajak yang memenuhi syarat patuh di Indonesia sedikit sekali jika dibandingkan dengan jumlah total wajib pajak terdaftar (Ilyas dan Burton, 2013).

Dewasa ini pajak merupakan pendapatan terbesar pada suatu negara yang digunakan untuk biaya operasional pemerintahan. Tetapi dalam menghimpun pajak dari masyarakat tidaklah mudah, karena timbal balik yang diterima oleh masyarakat atau wajib pajak tidak diperoleh secara langsung sehingga wajib pajak tidak merasa mendapat apapun dari pembayaran pajak yang telah dilakukan. Hal inilah yang menyebabkan para wajib pajak melakukan penghindaran pajak, bahkan seringkali terjadi perlawanan pajak. Selain itu adanya aparatur pajak atau fiskus yang melakukan korupsi 
menjadi pemicu yang serius bagi wajib pajak untuk tidak melakukan pembayaran pajak. Sistem pemungutan pajak yang digunakan di Indonesia adalah Self Assesment, dimana wajib pajak diberi wewenang untuk menghitung, menyetor dan melaporkan besarnya pajak yang terutang sesuai dengan jangka waktu yang telah ditentukan dalam peraturan perundang-undangan perpajakan. Salah satu wajib pajak yang diminta untuk menghitung, menyetor dan melaporkan besarnya pajak terutang adalah wajib pajak orang pribadi (Pujiwidodo, 2016).

Dalam rangka mencegah dan melakukan deteksi dini atas pelanggaran yang mungkin terjadi di lingkungan Direktorat Jenderal Pajak (DJP) melalui peningkatan peran serta pegawai dan masyarakat secara aktif untuk menjadi pelapor pelanggaran (Whistleblower), DJP telah menerbitkan Peraturan Direktur Jenderal Pajak Nomor PER-22/PJ/2011 tanggal 19 Agustus 2011 tentang Kewajiban Melaporkan Pelanggaran dan Penanganan Pelaporan Pelanggaran (Whistleblowing) di Lingkungan Direktorat Jenderal Pajak (Perdirjen Nomor PER-22/PJ/2011). Pemahaman mengenai Whistleblowing System Direktorat Jenderal Pajak diharapkan dapat mencegah dan mengurangi pelanggaran yang terjadi, membentuk budaya baru DJP yang korektif, serta meningkatkan kepatuhan pegawai DJP. Hal ini pada akhirnya diharapkan akan mendukung pencapaian sasaran penerimaan pajak yang optimal. Keputusan wajib pajak untuk menjadi patuh atau tidak patuh terhadap kewajiban perpajakannya merupakan tanggapan atas kondisi faktor internal dan eksternal dari wajib pajak. Berdasarkan latar belakang tersebut maka tujuan utama dari penelitian ini adalah : mengetahui dan menganalisis pengaruh antara penerapan Good Corporate Governance terhadap kepatuhan wajib pajak, mengetahui dan menganalisis pengaruh antara Whistleblowing System terhadap kepatuhan wajib pajak, mengetahui dan menganalisis jika dimoderasi oleh variabel risiko sanksi pajak apakah terdapat pengaruh antara penerapan Good Corporate Governance terhadap kepatuhan wajib pajak serta mengetahui dan menganalisis jika dimoderasi oleh variabel risiko sanksi pajak apakah terdapat pengaruh antara Whistleblowing System terhadap kepatuhan wajib pajak.

\section{TINJAUAN PUSTAKA DAN HIPOTESIS}

\section{Kepatuhan Wajib Pajak}

Kepatuhan perpajakan menurut Rustiyaningsih (2011) diartikan sebagai suatu keadaan yang mana wajib pajak patuh dan mempunyai kesadaran dalam memenuhi kewajiban perpajakan. Pada prinsipnya kepatuhan perpajakan adalah wajib pajak yang taat dan memenuhi serta melaksanakan kewajiban perpajakan sesuai dengan ketentuan peraturan perundang-undangan perpajakan (Sasmita, 2013). Reformasi birokrasi perpajakan merupakan reformasi menyeluruh dengan menerapkan dan melaksanakan Good Governance. Peraturan pemerintah No. 101 Tahun 2000, merumuskan good governance yaitu: "Kepemerintahan yang mengembangkan dan menerapkan prinsip-prinsip profesionalitas, akuntanbilitas, transparansi, pelayanan prima, demokrasi, efesiensi, efektivitas, supremasi hukum dan dapat diterima oleh seluruh masyarakat”.

Rahman (2009), dalam hasil penelitiannya yang menggunakan indikator good governance mengatakan bahwa good governance mempunyai pengaruh positif yang signifikan terhadap kepatuhan wajib pajak. Alijoyo dan Subartono (2014), menyebutkan Governance pada dasarnya berbicara tentang dua aspek yakni, governance structure dan governance process atau governance mechanism pada sebuah perusahaan. Governance structure adalah struktur hubungan pertanggungjawaban dan pembagian peran di antara berbagai organ utama perusahaan, yakni pemilik/pemegang saham, pengawas/komisaris, dan pengelola/manajemen. Sedangkan governance process adalah mekanisme kerja dan interaksi aktual di antara organ-organ tersebut.

\section{H1 : Terdapat pengaruh antara penerapan Good Corporate Governance terhadap kepatuhan wajib pajak}


Sedangkan penerapan Whistle Blowing System menjadi suatu alat yang dapat dipergunakan untuk mencegah kebocoran-kebocoran pajak yang dilakukan oleh fiskus dimana dalam rangka mencegah dan melakukan deteksi dini atas pelanggaran yang mungkin terjadi di lingkungan Direktorat Jenderal Pajak (DJP) melalui peningkatan peran serta pegawai dan masyarakat secara aktif untuk menjadi pelapor pelanggaran (Whistleblower), DJP telah menerbitkan Peraturan Direktur Jenderal Pajak Nomor PER22/PJ/2011 tanggal 19 Agustus 2011 tentang Kewajiban Melaporkan Pelanggaran dan Penanganan Pelaporan Pelanggaran (Whistle Blowing) di Lingkungan Direktorat Jenderal Pajak (Perdirjen Nomor PER-22/PJ/2011), Whistle Blowing System DJP juga dimaksudkan untuk membangun kembali public trust terhadap DJP dan mengajak seluruh pegawai DJP untuk mengubah budaya permisif menjadi budaya korektif yang berarti tidak akan pernah mentolerir adanya pelanggaran dengan cara melaporkannya ke saluran pengaduan yang telah disediakan.

\section{H2 : Terdapat pengaruh antara Whistleblowing System terhadap kepatuhan wajib pajak}

\section{Sanksi pajak}

Menurut Mardiasmo (2016), sanksi perpajakan merupakan alat pencegah (preventif) agar wajib pajak tidak melanggar norma pepajakan. Pelaksanaan sanksi pajak dapat menyebabkan terpenuhinya kewajiban perpajakan oleh wajib pajak, sehingga wajib pajak akan patuh karena mereka memikirkan adanya sanksi berat berupa denda akibat tindakan ilegal dalam usahanya menyelundupkan pajak (Pujiwidodo, 2016).

Kepatuhan wajib pajak masih perlu ditingkatkan dengan mendorong pelaksanaan perpajakan yang transparan, yaitu transparansi pengelolaan pajak di segala bidang, baik bidang administrasi maupun pengelolaan penggunaan dana yang bersumber dari pendapatan pajak tersebut (Siringoringo, 2015). Upaya nyata yang harus dilakukan untuk melaksankan transparansi tersebut adalah melalui gerakan reformasi birokrasi dalam sistem pelayanan dan administrasi perpajakan yaitu melalui penerapan dan pelaksanaan Good Governance. Good governance merupakan tata kelola organisasi yang dilaksanakan dengan baik, dengan menjalankan prisip-prinsip keterbukaan, keadilan dan dapat dipertanggungjawabkan dalam rangka mencapai tujuan dari organisasi (Lukviarman, 2016). Agar tujuan penerimaan pajak dapat tercapai dengan baik maka perlu ada proses penegakan hukum di bidang perpajakan apalagi dalam menegakkan self assessment system, karena hal tersebut sesuai dengan isi dari pengertian pajak sebagai iuran wajib yang dipaksakan sesuai dengan undang-undang, penegakan hukum berarti memberikan segala sanksi yang tepat dan adil atas pelanggaran yang dilakukan dalam pelaksanaan perpajakan.

\section{H3 : Terdapat pengaruh antara penerapan Good Corporate Governance terhadap kepatuhan wajib pajak jika dimoderasi oleh variabel risiko sanksi pajak}

Selain penerapan dan pelaksanaan Good Governance, juga perlu menerapkan system pengawasan yang lebih baik, yaitu dengan penerapan Whistle Blowing System yang mulai diterapkan pada tahun 2012 dengan dikeluarkannya Surat Edaran Direktur Jendral Pajak Nomor SE11/PJ/2011. Whistle Blowing system (WiSe) adalah sebuah aplikasi yang disediakan oleh kementerian keuangan bagi setiap orang yang memiliki informasi tentang adanya pelanggaran atau penyelewangan dan tindak kejahatan korupsi yang dilakukan oleh SDM yang ada dilingkungan Kementerian Keuangan Republik Indonesia. Pengadaan aplikasi ini menjadi sebuah bukti nyata yang ingin ditunjukkan oleh DJP kepada wajib pajak, bahwa DJP kini serius menghadapi dan memberantas korupsi maupun penyelewengan-penyelewengan yang ingin dilakukan oleh aparatur DJP, yang pada akhirnya diharapkan akan mampu mengembalikan kepercayaan masyarakat sehingga akan dapat menciptakan dan meningkatkan kepatuhan wajib pajak. 
H4 : Terdapat pengaruh antara penerapan Whistleblowing System terhadap kepatuhan wajib pajak jika dimoderasi oleh variabel risiko sanksi pajak

\section{Kerangka Konsep Penelitian}

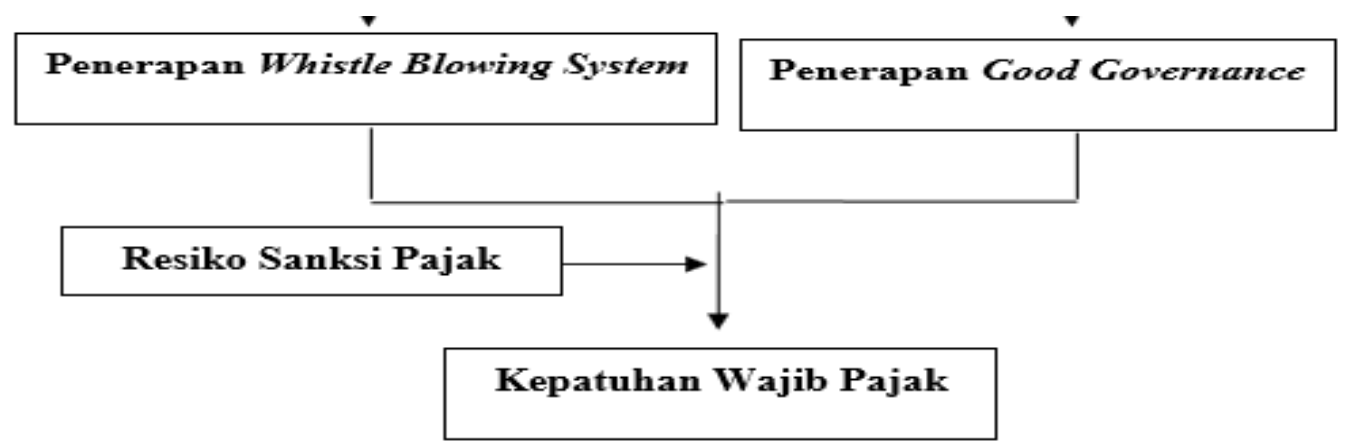

Gambar 1. Kerangka Konsep Penelitian

\section{METODE PENELITIAN}

\section{Jenis Penelitian}

Jenis penelitian yang dilakukan adalah penelitian kuantitatif kausalitas karena penelitian ini adalah untuk menguji hipotesis yang telah diajukan yaitu menguji pengaruh variabel-variabel independen terhadap variable dependen dan bagaimana pengaruhnya apabila ada variabel yang memoderasi variabel independen dan variabel dependen tersebut.

\section{Lokasi Penelitian}

Penelitian ini dilaksanakan di Kabupaten Sleman, Daerah Istimewa Yogyakarta.

\section{Definisi Operasional dan Pengukuran Variabel}

\section{Good Corporate Govenance (GCG)}

Good Corporate Governance (GCG) adalah hubungan antara manajemen atas perusahaan yaitu yang terdiri dari BoD, manajer senior, dan pemangku kepentingan yang mana merupakan mekanisme yang memberikan wewenang untuk mengendalikan perusahaan berdasarkan keputusan yang diambil oleh manajemen atas (Tricker, 2004). Indikator pengukuran prosedur implementasi Good Corporate Governance (GCG) adalah (1) Integrity and impartiality - bekerja secara tuntas, ber etika dan sesuai kepentingan Instansi. (2) Promoting the public good -menggunakan setiap peluang untuk meningkatkan nilai asset public dan institusi serta menjamin produktifitas dari penggunaan sumberdaya yang ada untuk mencapai tujuan organisasi. (3) Commitment to the system of government -tanggap terhadap kebutuhan pemerintah dan mengimplementasikan kebijakan dan keputusan secara keseluruhan dan professional. (4) Accountability and transparency -bertanggung jawab pada setiap keputusan yang diambil dan menyediakan mekanisme yang sesuai dalam rangka pemahaman standar -standar yang dipergunakan serta memiliki prosedur yang jelas, peran atau posisi dan tangggung yang jelas dalam pengambilan keputusan dan pelaksanaan otoritas. (5) Public defensibility -menjamin instansi berkomitmen untuk mencapai kebutuhan dan keinginan public dan memiliki mekanisme yang dibutuhkan untuk memastikan komitmen tersebut dapat dipertahankan.

\section{Whistleblowing}

Menurut Sisingoringo (2015), Whistleblowing didefinisikan sebagai sutu tindakan melaporkan pelanggaran dalam suatu organisasi kepada pihak lain baik di dalam maupun di luar organisasi. Indikator Whistleblowing dalam penelitian ini adalah : (a) Mencegah Pelaku Melakukan 
Pelanggaran (Asas Prevention). (b) Mendorong antusiasme whistleblower (Asas Early Detection). (c) Penanganan yang efektif (Asas Proper Investigation).

\section{Resiko sanksi pajak}

Resiko sanksi pajak merupakan suatu sanksi yang akan diterima apabila wajib pajak tidak patuh terhadap pelaksanaan kewajiban perpajakannya, namun sebaliknya sanksi tersebut tidak akan diterima apabila wajib pajak tersebut melaksanakan kewajiban perpajakannya sesuai dengan peraturan perpajakan yang berlaku (Siringoringo, 2015). Penerapan resiko sanksi pajak dalam system administrasi perpajakan melalui sanksi administrasi dilakukan agar tujuan penghimpunan dana dari masyarakat dapat tetap terlaksana, dimana sanksi administrasi tidak akan menghilangkan atau menghapus kewajiban perpajakan yang melekat pada wajib pajak yang dikenakan sanksi tersebut.

\section{Kepatuhan Wajib Pajak}

Kepatuhan perpajakan menurut Rustiyaningsih (2011) diartikan sebagai suatu keadaan yang mana wajib pajak patuh dan mempunyai kesadaran dalam memenuhi kewajiban perpajakan. Indikator yang digunakan untuk mengukur kepatuhan wajib pajak (Carolina dkk, 2011), yakni: (a) Benar dalam perhitungan pajak terhutang. (b) Benar dalam pengisian SPT. (c) Tepat waktu dalam melaporkan SPT. (d) Melakukan kewajiban dengan secara sukarela (atas kesadaran sendiri) sesuai dengan aturan perpajakan.

\section{Jenis dan Sumber Data}

Data adalah catatan keterangan sesuai bukti kebenaran, bahan bahan yang dipakai sebagai dukungan penelitian Dalam penelitian ini data yang digunakan terdiri dari data primer dan data sekunder.

\section{Populasi dan Sampel}

Populasi yang digunakan dalam penelitian adalah wajib pajak orang pribadi yang memiliki NPWP (Nomor Pokok Wajib Pajak) yang terdaftar di Kabupaten Sleman. Karena jumlah wajib pajak yang terdaftar di Kabupaten Sleman sangat besar, maka perlu dibuat sampling, dimana dari jumlah wajib pajak orang pribadi yang terdaftar di Kabupaten Sleman akan diambil sampel dengan mengunakan teknik pengambilan sampel yaitu non probability sampling, dimana pengambilan sampel tidak memperhitungkan semua anggota populasi mempunyai kesempatan yang sama untuk dipilih secara acak sebagai sampel, dan metode yang digunakan adalah convenience sampling (Ghozali, 2013). Metode ini sangat cocok digunakan dalam penelitian ini, dikarenakan jumlah wajib pajak pribadi yang begitu besar di wilayah Kabupaten Sleman. Oleh karena itu ada beberapa penulis menggunakan istilah accidental sampling - tidak disengaja - atau juga captive sample (man-on-thestreet).

\section{Teknik Analisis Data}

Untuk mengetahui apakah ada pengaruh yang signifikan dari beberapa variabel independen terhadap variabel dependen maka digunakan model regresi linier berganda yang dirumuskan sebagai berikut:

$$
\text { Kepatuhan }=\alpha+\beta_{1} \mathrm{CG}+\beta_{2} \mathrm{WBS}+\beta_{3} \mathrm{CG} * \mathrm{SANKSI}+\beta_{4} \mathrm{WBS} * \mathrm{SANKSI}+\mathrm{e}
$$

Keterangan :

$\begin{array}{llll}\alpha & =\text { Konstanta } & \text { CG } & =\text { Corporate Governance } \\ \beta 1-\beta 4 & =\text { Koefisien regresi } & \text { WBS } & =\text { Whistleblowing System } \\ \text { Kepatuhan } & =\text { Kepatuhan Wajib } & \text { SANKSI } & =\text { Sanksi Pajak } \\ \text { Pajak } & & \text { e } & =\text { Nilai Error }\end{array}$




\section{HASIL PENELITIAN}

Dari hasil uji validitas dan reliabilitas diperoleh hasil sebagai berikut :

Tabel 1. Uji Validitas dan Reliabilitas

\begin{tabular}{|c|c|c|c|c|c|}
\hline Variabel & Indikator & $\begin{array}{c}\text { Pearson } \\
\text { Correlation }\end{array}$ & Signifikansi & Keterangan & $\begin{array}{c}\text { Cronbach's } \\
\text { Alpha }\end{array}$ \\
\hline \multirow{10}{*}{$\begin{array}{c}\text { GOOD CORPORATE } \\
\text { GOVERNANCE }\end{array}$} & Item 1 & 0,757 & 0,000 & Valid & \multirow{10}{*}{0,920} \\
\hline & Item 2 & 0,925 & 0,000 & Valid & \\
\hline & Item 3 & 0,775 & 0,000 & Valid & \\
\hline & Item 4 & 0,757 & 0,000 & Valid & \\
\hline & Item 5 & 0,775 & 0,000 & Valid & \\
\hline & Item 6 & 0,775 & 0,000 & Valid & \\
\hline & Item 7 & 0,467 & 0,009 & Valid & \\
\hline & Item 8 & 0,798 & 0,000 & Valid & \\
\hline & Item 9 & 0,925 & 0,000 & Valid & \\
\hline & Item 10 & 0,824 & 0,000 & Valid & \\
\hline \multirow{10}{*}{$\begin{array}{l}\text { WHISTLEBLOWING } \\
\text { SYSTEM }\end{array}$} & Item 1 & 0,460 & 0,011 & Valid & \multirow{10}{*}{0,829} \\
\hline & Item 2 & 0,870 & 0,000 & Valid & \\
\hline & Item 3 & 0,953 & 0,000 & Valid & \\
\hline & Item 4 & 0,561 & 0,001 & Valid & \\
\hline & Item 5 & 0,470 & 0,009 & Valid & \\
\hline & Item 6 & 0,460 & 0,011 & Valid & \\
\hline & Item 7 & 0,746 & 0,000 & Valid & \\
\hline & Item 8 & 0,396 & 0,030 & Valid & \\
\hline & Item 9 & 0,423 & 0,020 & Valid & \\
\hline & Item 10 & 0,953 & 0,000 & Valid & \\
\hline \multirow{5}{*}{ RISIKO SANKSI PAJAK } & Item 1 & 0,958 & 0,000 & Valid & \multirow{5}{*}{0,943} \\
\hline & Item 2 & 0,962 & 0,000 & Valid & \\
\hline & Item 3 & 0,682 & 0,000 & Valid & \\
\hline & Item 4 & 0,453 & 0,012 & Valid & \\
\hline & Item 5 & 0,802 & 0,000 & Valid & \\
\hline
\end{tabular}




\begin{tabular}{|c|c|c|c|c|c|}
\hline & Item 6 & 0,691 & 0,000 & Valid & \\
\hline & Item 7 & 0,903 & 0,000 & Valid & \\
\hline & Item 8 & 0,958 & 0,000 & Valid & \\
\hline & Item 9 & 0,453 & 0,012 & Valid & \\
\hline & Item 10 & 0,440 & 0,016 & Valid & \\
\hline & Item 11 & 0,903 & 0,000 & Valid & \\
\hline & Item 12 & 0,707 & 0,000 & Valid & \\
\hline \multirow{12}{*}{$\begin{array}{l}\text { KEPATUHAN WAJIB } \\
\text { PAJAK }\end{array}$} & Item 1 & 0,451 & 0,012 & Valid & \multirow{12}{*}{0,860} \\
\hline & Item 2 & 0,622 & 0,000 & Valid & \\
\hline & Item 3 & 0,782 & 0,000 & Valid & \\
\hline & Item 4 & 0,466 & 0,009 & Valid & \\
\hline & Item 5 & 0,908 & 0,000 & Valid & \\
\hline & Item 6 & 0,441 & 0,015 & Valid & \\
\hline & Item 7 & 0,580 & 0,001 & Valid & \\
\hline & Item 8 & 0,934 & 0,000 & Valid & \\
\hline & Item 9 & 0,931 & 0,000 & Valid & \\
\hline & Item 10 & 0,577 & 0,001 & Valid & \\
\hline & Item 11 & 0,782 & 0,000 & Valid & \\
\hline & Item 12 & 0,479 & 0,007 & Valid & \\
\hline
\end{tabular}

Sumber : Data diolah, 2018

Berdasarkan tabel diatas, diperoleh nilai $r_{\text {hitung }}$ dari semua item kuesioner meliputi variabel penelitian yaitu good corporate governance, whistleblowing system, risiko sanksi pajak, dan kepatuhan wajib pajak menunjukkan nilai angka probabilitas (sig) $<0.05$. Sehingga kuesioner dari variabel-variabel yaitu good corporate governance, whistleblowing system, risiko sanksi pajak, dan kepatuhan wajib pajak valid, serta diperoleh nilai nilai Alpha Cronbach dari semua hasil meliputi variabel penelitian menunjukkan lebih besar dari nilai 0,6. Dengan demikian jawaban-jawaban responden dari variabel-variabel penelitian yaitu good corporate governance, whistleblowing system, risiko sanksi pajak, dan kepatuhan wajib pajak, sehingga kuesioner dari variabel-variabel tersebut reliabel dan dapat digunakan untuk penelitian selanjutnya.

Untuk menguji hipotesis dalam penelitian ini digunakan model regresi linier berganda. Analisis regresi linier berganda di gunakan untuk memperoleh gambaran yang menyeluruh mengenai pengaruh antara good corporate governance, whistleblowing system, moderasi risiko sanksi pajak, terhadap kepatuhan wajib pajak. Hasil perhitungan regresi linier berganda disajikan pada Tabel berikut : 
Tabel 2. Regresi Linear Berganda

\begin{tabular}{|c|c|c|c|}
\hline Variabel & Koef. Reg & $\mathbf{t}$ & Sig \\
\hline$($ Constant $)$ & \multicolumn{3}{|c|}{,490 } \\
\hline GCG & ,027 & 6,093 & 000 \\
\hline Whistleblowing & ,016 & 5,194 & ,003 \\
\hline$G C G$ dimoderasi risiko sanksi pajak. & ,018 & 1,597 &, 110 \\
\hline Whistleblowing dimoderasi risiko sanksi pajak &, 012 & 1,970 & 049 \\
\hline $\mathrm{F}$ & \multicolumn{3}{|c|}{1918,130} \\
\hline Sig & \multicolumn{3}{|c|}{, 000} \\
\hline Adj $R$ Square & \multicolumn{3}{|c|}{,364 } \\
\hline
\end{tabular}

Sumber : Data diolah, 2018

\section{Pengaruh antara penerapan Good Corporate Governance terhadap kepatuhan wajib pajak}

Berdasarkan hasil uji t untuk good corporate governance memperoleh $p$ value sebesar 0,000 , oleh karena itu nilai sig $\mathrm{t}(0,000)<0,05$ yang berarti hipotesis diterima. Jadi, dapat disimpulkan bahwa terdapat pengaruh antara penerapan Good Corporate Governance terhadap kepatuhan wajib pajak. Kepatuhan perpajakan menurut Rustiyaningsih (2011) diartikan sebagai suatu keadaan yang mana wajib pajak patuh dan mempunyai kesadaran dalam memenuhi kewajiban perpajakan. Pada prinsipnya kepatuhan perpajakan adalah wajib pajak yang taat dan memenuhi serta melaksanakan kewajiban perpajakan sesuai dengan ketentuan peraturan perundang-undangan perpajakan (Sasmita, 2013). Reformasi birokrasi perpajakan merupakan reformasi menyeluruh dengan menerapkan dan melaksanakan Good Governance. Peraturan pemerintah No. 101 Tahun 2000, merumuskan good governance yaitu: "Kepemerintahan yang mengembangkan dan menerapkan prinsip-prinsip profesionalitas, akuntanbilitas, transparansi, pelayanan prima, demokrasi, efesiensi, efektivitas, supremasi hukum dan dapat diterima oleh seluruh masyarakat". Rahman (2009), dalam hasil penelitiannya yang menggunakan indikator good governance mengatakan bahwa good governance mempunyai pengaruh positif yang signifikan terhadap kepatuhan wajib pajak. Alijoyo (2014), menyebutkan Governance pada dasarnya berbicara tentang dua aspek yakni, governance structure dan governance process atau governance mechanism pada sebuah perusahaan. Governance structure adalah struktur hubungan pertanggungjawaban dan pembagian peran di antara berbagai organ utama perusahaan, yakni pemilik/pemegang saham, pengawas/komisaris, dan pengelola/manajemen. Sedangkan governance process adalah mekanisme kerja dan interaksi aktual di antara organ-organ tersebut.

\section{Pengaruh antara Whistleblowing System terhadap kepatuhan wajib pajak}

Berdasarkan hasil uji t untuk Whistleblowing System memperoleh $p$ value sebesar 0,003, oleh karena itu nilai sig t $(0,003)<0,05$ yang berarti hipotesis diterima. Jadi, dapat disimpulkan bahwa terdapat pengaruh antara penerapan Whistleblowing System terhadap kepatuhan wajib pajak. Penerapan Whistle Blowing System menjadi suatu alat yang dapat dipergunakan untuk mencegah 
kebocoran-kebocoran pajak yang dilakukan oleh fiskus dimana dalam rangka mencegah dan melakukan deteksi dini atas pelanggaran yang mungkin terjadi di lingkungan Direktorat Jenderal Pajak (DJP) melalui peningkatan peran serta pegawai dan masyarakat secara aktif untuk menjadi pelapor pelanggaran (Whistleblower), DJP telah menerbitkan Peraturan Direktur Jenderal Pajak Nomor PER22/PJ/2011 tanggal 19 Agustus 2011 tentang Kewajiban Melaporkan Pelanggaran dan Penanganan Pelaporan Pelanggaran (Whistle Blowing) di Lingkungan Direktorat Jenderal Pajak (Perdirjen Nomor PER-22/PJ/2011), Whistle Blowing System DJP juga dimaksudkan untuk membangun kembali public trust terhadap DJP dan mengajak seluruh pegawai DJP untuk mengubah budaya permisif menjadi budaya korektif yang berarti tidak akan pernah mentolerir adanya pelanggaran dengan cara melaporkannya ke saluran pengaduan yang telah disediakan.

\section{Pengaruh antara penerapan Good Corporate Governance terhadap kepatuhan wajib pajak jika dimoderasi oleh variabel risiko sanksi pajak}

Berdasarkan hasil uji t untuk Good Corporate Governance terhadap kepatuhan wajib pajak jika dimoderasi oleh variabel risiko sanksi pajak memperoleh $\mathrm{p}$ value sebesar 0,110 , oleh karena itu nilai sig $\mathrm{t}(0,110)>0,05$ yang berarti hipotesis ditolak. Jadi, dapat disimpulkan bahwa tidak terdapat pengaruh antara penerapan Good Corporate Governance terhadap kepatuhan wajib pajak jika dimoderasi oleh variabel risiko sanksi pajak. Menurut Mardiasmo (2016), sanksi perpajakan merupakan alat pencegah (preventif) agar wajib pajak tidak melanggar norma pepajakan. Pelaksanaan sanksi pajak dapat menyebabkan terpenuhinya kewajiban perpajakan oleh wajib pajak, sehingga wajib pajak akan patuh karena mereka memikirkan adanya sanksi berat berupa denda akibat tindakan ilegal dalam usahanya menyelundupkan pajak (Pujiwidodo, 2016). Kepatuhan wajib pajak masih perlu ditingkatkan dengan mendorong pelaksanaan perpajakan yang transparan, yaitu transparansi pengelolaan pajak di segala bidang, baik bidang administrasi maupun pengelolaan penggunaan dana yang bersumber dari pendapatan pajak tersebut (Siringoringo, 2015). Upaya nyata yang harus dilakukan untuk melaksankan transparansi tersebut adalah melalui gerakan reformasi birokrasi dalam sistem pelayanan dan administrasi perpajakan yaitu melalui penerapan dan pelaksanaan Good Governance.

Good governance merupakan tata kelola organisasi yang dilaksanakan dengan baik, dengan menjalankan prisip-prinsip keterbukaan, keadilan dan dapat dipertanggungjawabkan dalam rangka mencapai tujuan dari organisasi (Lukviarman, 2016). Agar tujuan penerimaan pajak dapat tercapai dengan baik maka perlu ada proses penegakan hukum di bidang perpajakan apalagi dalam menegakkan self assessment system, karena hal tersebut sesuai dengan isi dari pengertian pajak sebagai iuran wajib yang dipaksakan sesuai dengan undang-undang, penegakan hukum berarti memberikan segala sanksi yang tepat dan adil atas pelanggaran yang dilakukan dalam pelaksanaan perpajakan.

tidak terdapat pengaruh antara penerapan Good Governance terhadap kepatuhan wajib pajak jika dimoderasi oleh variabel risiko sanksi pajak menurut La Porta et al (1998) bahwa sesuai dengan pendekatan hukum dan keuangan di dalam memahami praktek corporate governance

di suatu negara, karakteristik corporate governance yang diterapkan di Indonesia mengikuti pola tradisi hukum Perancis (The French Law Tradition). Peneliti ini mengidentifikasi bahwa kelemahan penerapan corporate governance di Indonesia berasal dari sudut pandang hukum/legal dan lingkungan regulasi sehingga penguatan terhadap hal tersebut merupakan hal penting dan krusial dalam meningkatkan kualitas praktik corporate governance di Indonesia. Rendahnya budaya kepatuhan (compliance) dan penegakan aturan hukum (enforcement) sebagai masalah paling besar. Kondisi demikian mempengaruhi substansi implementasi dan praktik corporate governance di Indonesia terutama dalam kaitannya dengan kepatuhan wajib pajak. Pelaksanaan corporate governance menjadi sia-sia, oleh karena itu sangat penting bagi Direktorat Jendral Pajak untuk melakukan sosialisasi yang menyeluruh kepada wajib pajak orang pribadi di kabupaten Sleman, 
bahwa sekarang ini DJP telah menjalankan corporate governance dalam menjalankan fungsinya, serta harus diterapkan secara maksimal dan berkelanjutan.

\section{Pengaruh antara penerapan Whistleblowing System terhadap kepatuhan wajib pajak jika dimoderasi oleh variabel risiko sanksi pajak}

Berdasarkan hasil uji t untuk Whistleblowing System terhadap kepatuhan wajib pajak jika dimoderasi oleh variabel risiko sanksi pajak memperoleh $\mathrm{p}$ value sebesar 0,049 , oleh karena itu nilai sig $\mathrm{t}(0,049)<0,05$ yang berarti hipotesis diterima. Jadi, dapat disimpulkan bahwa terdapat pengaruh antara penerapan Whistleblowing System terhadap kepatuhan wajib pajak jika dimoderasi oleh variabel risiko sanksi pajak.

Undang-Undang No 13 tahun 2006 tentang perlindungan saksi dan korban telah mengatur perlindungan bagi saksi dan korban pelapor suatu perkara pidana. Undang-undang ini dapat digunakan sebagai acuan atau pedoman bagi perusahaan untuk menyusun suatu mekanisme whistleblowing. Pada tahun 2008, Komite Nasional Kebijakan Governance telah mengeluarkan pedoman khusus tentang system dan prosedur whistleblowing. Pelanggaran yang dapat dilaporkan melalui whistleblowing system antara lain mencakup pelanggaran peraturan perundang-undangan, kode etik perusahaan, prinsip akuntansi yang berlaku umum, kebijakan dan prosedur operasional perusahaan ataupun tindakan kecurangan lainnya. Pada umumnya pengungkapan adanya pelanggaran di berbagai perusahaan tersebut dilakukan secara rahasia. Whistle Blowing system yang terjadi di lingkungan perusahaan sangat memerlukan peran serta seluruh unsur perusahaan dalam proses pengungkapan maupun pelaporannya. Whistle Blowing system merupakan bagian dari system pengendalian internal dalam upaya pencegahan dan pendeteksian praktik penyimpangan dan kecurangan serta dalam rangka memperkokoh implementasi GCG.

Selain penerapan dan pelaksanaan Good Governance, juga perlu menerapkan system pengawasan yang lebih baik, yaitu dengan penerapan Whistle Blowing System yang mulai diterapkan pada tahun 2012 dengan dikeluarkannya Surat Edaran Direktur Jendral Pajak Nomor SE11/PJ/2011. Whistle Blowing system (WiSe) adalah sebuah aplikasi yang disediakan oleh kementerian keuangan bagi setiap orang yang memiliki informasi tentang adanya pelanggaran atau penyelewangan dan tindak kejahatan korupsi yang dilakukan oleh SDM yang ada dilingkungan Kementerian Keuangan Republik Indonesia. Pengadaan aplikasi ini menjadi sebuah bukti nyata yang ingin ditunjukkan oleh DJP kepada wajib pajak, bahwa DJP kini serius menghadapi dan memberantas korupsi maupun penyelewengan-penyelewengan yang ingin dilakukan oleh aparatur DJP, yang pada akhirnya diharapkan akan mampu mengembalikan kepercayaan masyarakat sehingga akan dapat menciptakan dan meningkatkan kepatuhan wajib pajak.

\section{KESIMPULAN DAN SARAN}

\section{Kesimpulan}

1. Berdasarkan hasil uji regresi linear berganda menunjukkan bahwa terdapat pengaruh antara penerapan Good Corporate Governance terhadap kepatuhan wajib pajak

2. Berdasarkan hasil uji regresi linear berganda menunjukkan bahwa terdapat pengaruh antara penerapan Whistleblowing System terhadap kepatuhan wajib pajak

3. Berdasarkan hasil uji regresi linear berganda menunjukkan bahwa tidak terdapat pengaruh antara penerapan Good Corporate Governance terhadap kepatuhan wajib pajak jika dimoderasi oleh variabel risiko sanksi pajak 
4. Berdasarkan hasil uji regresi linear berganda menunjukkan bahwa terdapat pengaruh antara penerapan Whistleblowing System terhadap kepatuhan wajib pajak jika dimoderasi oleh variabel risiko sanksi pajak

\section{Rekomendasi Penelitian Selanjutnya}

Jenis penelitian yang dilakukan adalah penelitian kuantitatif kausalitas karena penelitian ini adalah untuk menguji hipotesis yang telah diajukan yaitu menguji pengaruh variabel-variabel independen terhadap variable dependen dan bagaimana pengaruhnya apabila ada variabel yang memoderasi variabel independen dan variabel dependen tersebut, sehingga banyak informasi yang tidak mungkin dikaji lebih mendalam untuk menginterpretasikan pengaruh variabel-variabel bebas terhadap variabel terikatnya. Kemudian teknik pengumpulan data yang dilakukan melalui instrumen kuesioner dalam mengukur variabel penelitian. Dalam penelitian ini, peran Good Corporate Governance memoderasi tidak terbukti, hal ini diduga karena responden yang dijadikan sebagai sampel tidak dipilih secara spesifik, untuk itu bagi peneliti berikutnya yang tertarik untuk meneliti variabel-variabel dalam penelitian ini diharapkan dapat memilih respondennya secara tepat, yaitu responden yang memang tidak memperoleh tunjangan pajak penghasilan atau pajak penghasilannya. Pelaksanaan corporate governance menjadi sia-sia, oleh karena itu sangat penting bagi Direktorat Jendral Pajak untuk melakukan sosialisasi yang menyeluruh kepada wajib pajak orang pribadi di kabupaten Sleman, bahwa sekarang ini DJP telah menjalankan corporate governance dalam menjalankan fungsinya, serta harus diterapkan secara maksimal dan berkelanjutan.

\section{DAFTAR PUSTAKA}

Alijoyo, A., dan Subartono, Z., (2004), Komisaris Independen: Penggerak Praktik GCG di Perusahaan, PT. Indeks, Jakarta.

Ghozali, I., (2013), Structural Equation Modeling Teori, Konsep, dan Aplikasi Dengan Lisrel 8.80 (Edisi 3), Universitas Diponegoro, Semarang.

Ilyas. B dan Burton, (2013), Hukum Pajak, Edisi 6, Salemba Empat, Jakarta.

La Porta, R. et al, (1998), Corporate Ownership Around the World, Journal of Finance, 471-577.

Lukviarman, N., (2016), Corporate Goernance, Era Adicitra Intermedia, Solo.

Mardiasmo, (2016), Perpajakan Edisi terbaru 2016, Andi, Yogyakarta.

Peraturan Direktur Jenderal Pajak Nomor PER-22/PJ/2011 tanggal 19 Agustus 2011.

Peraturan Pemerintah No. 101 Tahun 2000.

Pujiwododo, D., (2016). Persepsi Sanksi Perpajakan Terhadap Kepatuhan Wajib Pajak Orang Pribadi, Jurnal Online Insan Akuntan, Vol 1, No 1, Juni 2016, 92 - 116.

Rahman, A., (2009), Hubungan Sistem Administrasi Perpajakan Modern Dengan Kepatuhan Wajib Pajak, Jurnal Ilmu Administrasi, Vol VI. No 1.

Rustiyaningsih, S., (2010), Faktor-faktor yang Mempengaruhi Kepatuhan Wajib Pajak. Jurnal Akuntansi, Fakultas Ekonomi Universitas Katolik Widya Mandala Madiun, Vol 2. No 11.

Sasmita, S.N.A., (2013), Pengaruh Pemahaman Wajib Pajak, Pelayanan Fiskus, Kesadaran Wajib Pajak, dan Sanksi Perpajakan terhadap Kepatuhan Wajib Pajak Pemilik Usaha Kecil 
Menengah dalam Laporan Kewajiban Perpajakan di Semarang (Studi UMKM di Semarang), Jurnal Akuntansi, Universitas Brawijaya, Vol 7. No 9.

Sisingoringo, W., (2015), Pengaruh Good Governance dan Whistleblowing System Terhadap Kepauhan Wajib Pajak Orang Pribadi Dengan Risiko Sanksi Pajak Sebagai Variabel Moderating (Studi Empiris Terhadap Wajib Pajak Orang Pribadi Di Kota Bekasi), Jurnal Akuntansi, Volume XIX, No. 02, Mei; 207-224.

Surat Edaran Direktur Jendral Pajak Nomor SE-11/PJ/2011

Tricker, B., (2004), Corporate Governance : Principles, Policies and Practices,University Press Oxford, Oxford. 